\title{
Evaluating Air Pollution Tolerance Index (APTI) of Two Plant Species from Industrial Area of Jodhpur
}

\author{
Saraswat Punit ${ }^{*}$, Ashita Rai \\ Department of Zoology \& Environmental Science, Lachoo Memorial College of Science \& Technology (Autonomous), Jodhpur, India \\ Email address: \\ punit_saraswat2003@yahoo.co.in (S. Punit), ashitarai1911@gmail.com (A. Rai) \\ *Corresponding author
}

\section{To cite this article:}

Saraswat Punit, Ashita Rai. Evaluating Air Pollution Tolerance Index (APTI) of Two Plant Species from Industrial Area of Jodhpur. International Journal of Energy and Environmental Science. Vol. 6, No. 1, 2021, pp. 11-15. doi: 10.11648/j.ijees.20210601.12

Received: March 30, 2021; Accepted: April 13, 2021; Published: April 26, 2021

\begin{abstract}
Jodhpur is the second largest district in the state of Rajasthan. With growth in the population numbers of vehicles along with industries have increased which is affecting the air quality of Jodhpur. Plants have a very close relationship with nature and they act as sink for reducing air pollution. Impact of air pollution on two plants namely Tabernaemontana and Sesbania (vegetable humming bird tree) from heavy industrial area site (HI) Phase II were evaluated in terms of air pollution tolerance index (APTI) by analysing four biochemical parameters namely, total chlorophyll, ascorbic acid, relative water content (RWC), and pH using standard methods. Fresh and mature leaves were collected every month from August 2019 to March 2020 in morning hours between 8.00 AM and 9.00 AM and total number of vehicles (between 8.00 AM and 4.00 PM) were counted. Average APTI values for Tabernaemontana and Sesbania were found to be 7.13 and 5.90 respectively and hence both the plants fall in the sensitive category. APTI showed a positive correlation with $\mathrm{pH}$, RWC, and ascorbic acid but negative correlation with total chlorophyll in Tabernaemontana, while in Sesbania APTI showed a positive correlation with, relative water content RWC, and total chlorophyll and negative correlation with ascorbic acid and pH. The ascorbic acid content was found to be maximum in both Tabernaemontana and Sesbania in October 2019 (2.0 and 1.66). Relative water content and ascorbic acid of both plants were minimum in November 2019 (RWC 41.79 and 36.81) and August 2019 (0.4487 and 0.2682 ) respectively.
\end{abstract}

Keywords: Air Pollution Tolerance Index (APTI), Jodhpur, Industrial Area, Biochemical Parameters

\section{Introduction}

With the advent of urbanization and industrialization major changes have occurred in the air quality of most of the Indian cities and this is not only affecting the humans but also the plants and trees. Air pollution is a problem which we humans have given birth and today this baby has grown to a monster form. We can survive for a day or two without food but without air it is only few seconds. Ambient air quality levels exceeds the WHO levels in 36 major Indian cities and towns, resulting in 40 thousand premature deaths, around 19 million respiratory hospital admissions and sickness requiring medical treatment annually. According to the report published by World health organization (WHO) in 2014, air pollution is cause of death, for around 7 million people worldwide and air pollution levels remain dangerously high in many parts of the world. New data from same organization points that 9 out of 10 people breathe air containing high levels of pollutants. In India, every year 11-12 lakh people die due to air pollution. According to World air quality report 2020 , India continues to feature prominently at the top of the most polluted cities ranking, with 22 of the top 30 most polluted cities globally.

The reports quoted above paint a very grim picture we are facing today and may face more severe in the future. A trailer of such situation we had already seen in Delhi, when the smog in winters of 2017 choked people of Delhi forcing them to remain indoors.

Plants are beautiful gift of nature which can provide solutions to many problems including diseases like COVID19, which we are presently facing. They can reduce air pollutants and can help greatly in reducing noise pollution level. Leaves of plants are the one which come in direct contact with air pollutant. The pollutant level affects their 
chlorophyll content, $\mathrm{pH}$, ascorbic acid content and relative water contents. Most plants experience internal changes before showing noticeable injury to leaves when they are exposed to air pollutants. Air pollution tolerance index (APTI) is a scale which helps in measuring the potential of vegetation to encounter air pollution and can help in selecting tolerant species.

Keeping in view the above facts, present study was undertaken to evaluate air pollution tolerance index (APTI) of two plant species namely Tabernaemontana and Sesbania (vegetable humming bird tree) from industrial area of Jodhpur.

\section{Material and Methods}

\subsection{Area of Study}

Jodhpur is the second largest district in the state of Rajasthan. It is situated in western region of Rajasthan. The district has a geographical area of $22850 \mathrm{sq}$. km. which is $11.6 \%$ of total arid zone of the state. The general slope of terrain is towards west. Jodhpur district located between $26.28^{\circ}$ North latitude and $73.02^{\circ}$ East longitude. It shares common borders with five districts i.e. Bikaner and Jaisalmer in north and north west, Barmer and Pali in south west and and Nagaur in north east. In general the climate of Jodhpur district is hot, dry and sunny. The average rainfall is around 360 millimeters. The height of Jodhpur in relation to sea level is $231 \mathrm{mt}$. Temperatures are extreme from March to October, except when the monsoonal rain produces thick clouds to lower it slightly. Months of April, May and June, record high temperatures, routinely exceed 40 degrees Celsius. The study area, heavy industrial area site (HI) Phase II, is located between $26.24^{\circ}$ North latitude and $73.01^{\circ}$ East longitude. Industrial area site HI Phase II have industries dealing in handicrafts, pipes, bearings, guar gum, packing material, textiles, artistic furniture's etc and have high traffic load, mainly of heavy motor vehicles (HMV) throughout the day. Total numbers of vehicles (between 8.00 AM and 4.00 PM) were counted.

\subsection{Sampling Procedure}

Two plants were selected from study area (heavy industrial (HI) Phase II), namely - Tabernaemontana and Sesbania (vegetable humming bird tree) for APTI (air pollution tolerance index) analysis. Fresh matured leaves of selected plants; about 2 meters from ground were collected every month from August 2019 to March 2020, in morning hours between 8.00AM -9.00AM. Collected leaves were sealed in polythene bags at the site and brought to lab for biochemical analysis. Before analysis leaves were washed in running water to remove dust.

Parameters like Chlorophyll a, Chlorophyll b, Total Chlorophyll were analyzed according to method described [4], Ascorbic acid was measured by titrimetric method (using 2, 6-Dichlorophenol indo phenol dye.), Relative water content (RWC), and APTI (air pollution tolerance index) were estimated according to Singh and Rao [16]. pH was estimated using $\mathrm{pH}$ meter (Systronics water analyzer Model
371). The formulas used for calculation are

\subsubsection{Chlorophyll}

Chlorophyll $\mathrm{a}=12.7$ (A663) - 2.69 (A645) x V/1000W $\mathrm{mg} / \mathrm{g}$

Chlorophyll b=22.9 (A645) - 4.68 (A663) x V/1000W $\mathrm{mg} / \mathrm{g}$

Total Chlorophyll $\mathrm{TCh}=$ Chlorophyll $\mathrm{a}+\mathrm{b} \mathrm{mg} / \mathrm{g}$

Where, $A=$ Absorbance of the extract at the wavelength in $\mathrm{nm}, \mathrm{V}=$ total volume of the chlorophyll solution $(\mathrm{ml})$, and $\mathrm{W}=$ weight of the tissue extract $(\mathrm{g})$.

\subsubsection{Ascorbic Acid (AA)}

Titrimetric Method Was Used to Analyze the Ascorbic Content of the Sample Using 2,6,-Dichlorophenol Indophenol Dye

\subsubsection{Relative Water Content $\%=R W C=[(F W-D W) /(T W-$ $\mathrm{DW})] \times 100$}

Where,

$\mathrm{FW}=$ Fresh weight $(\mathrm{gm})$

TW=Turgid weight $(\mathrm{gm})$

DW=Dry weight (gm)

\subsection{4. $\mathrm{pH}$}

$\mathrm{pH}$ was measured by $\mathrm{pH}$ meter.

\subsubsection{The Air Pollution Tolerance Indices for the Selected Plants Were Determined Using the Following Formula}

$$
\mathrm{APTI}=(\mathrm{A}[\mathrm{T}+\mathrm{P}]+\mathrm{R}) / 10
$$

Where, $\mathrm{A}=$ Ascorbic Acid content $(\mathrm{mg} / \mathrm{g}), \mathrm{T}=$ Total Chlorophyll content $(\mathrm{mg} / \mathrm{g}), \mathrm{P}=\mathrm{pH}$ of leaf extract, and $\mathrm{R}=$ Relative Water content of leaf $(\%)$.

\subsubsection{Plants Were Classified According to APTI Values [12] APTI value \\ Less than $1=$ Highly sensitive \\ Between 1 - 16=Sensitive \\ Between 17-29=Intermediate tolerant \\ Between $30-100=$ tolerant}

\subsubsection{Correlation}

Correlation was calculated to find strength of relationship among different variables for both plants collected from sampling sites.

\section{Result and Discussion}

\subsection{Leaf Extract pH}

The leaf extract pH of Tabernaemontana and Sesbania was found to be maximum in February 2019 (6.91) and December 2019 (5.48) respectively. Minimum values were observed for Tabernaemontana in October 2019 (2.24) while for Sesbania it was observed in January 2020 (3.56) Figure 1 \& Figure 2.

The $\mathrm{pH}$ plays a significant role in plants physiological processes [20]. Most of the enzymes, involved in biological 
activities of the organism, require relatively high $\mathrm{pH}$ for their effective functioning. The presence of $\mathrm{SO}_{2}$ and $\mathrm{NOx}$ in the ambient air causes a shift in $\mathrm{pH}$ of leaf sap towards acidic value, due to diffusion of $\mathrm{SO}_{2}$ through stomata. Gaseous $\mathrm{SO}_{2}$ tends to dissolve in water forming sulphites, bisulphate and their ionic species with the generation of protons inducing the cellular $\mathrm{pH}$ [15]. High $\mathrm{pH}$ may increase the efficiency of conversion from hexose sugar to ascorbic acid [5] while low leaf $\mathrm{pH}$ extract show good correlation with sensitivity to pollution level and also reduce photosynthesis process in plants. So plants with relatively low $\mathrm{pH}$ are more susceptible, while those with $\mathrm{pH}$ around 7 are tolerant [11].

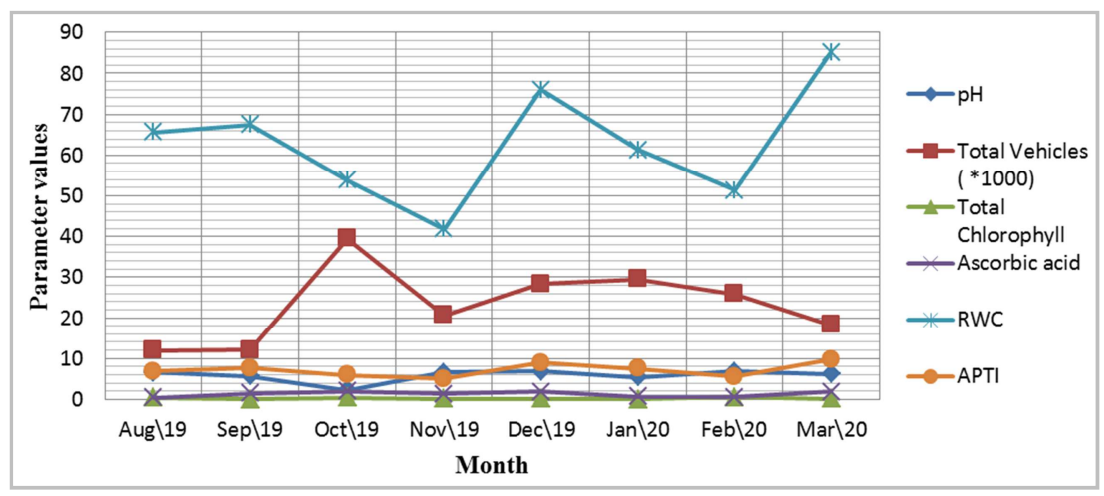

Figure 1. Relation between different parameters for Tabernaemontana at study area.

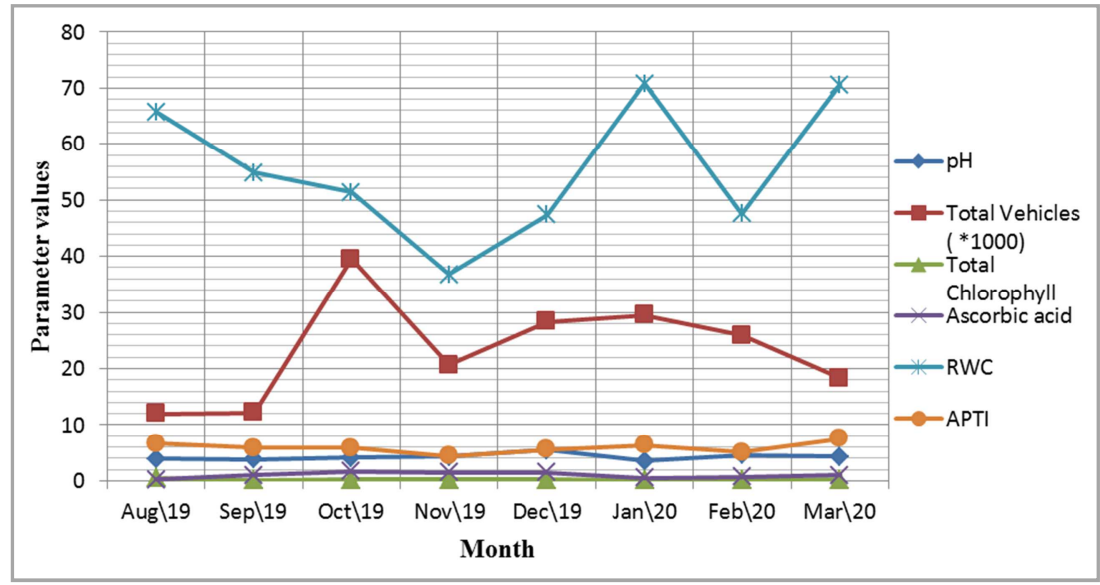

Figure 2. Relation between different parameters for Sesbania at study area.

\subsection{Total Chlorophyll}

Total chlorophyll content was found maximum in Tabernaemontana and Sesbania in February 2020 (0.5728) and August 2019 (0.4682) respectively and minimum values were observed in January 2020 (0.0780) and September 2019 (0.0890) respectively. Figure 1 \& Figure 2

Degradation of photosynthetic pigments has been widely used as an indicator of air pollution. The attack of air pollutants is always at the chloroplast. Air pollutants enter into the tissues through stomata and cause partial denaturation of the chloroplast which cause reduction in the pigment content of the cells of polluted leaves [15].

The decrease in chlorophyll content of leaves may be due to the alkaline condition created by the dissolution of chemical present in dust particles i.e. metals and polycyclic hydrocarbons in cell sap which block the stomatal spores for diffusion of air and thus put stress on plant metabolism resulting in chlorophyll degradation [3]. Moreover, it has been found that pollution generated through automobiles is one of the biggest reasons in decreasing chlorophyll content in plant growing along roadsides [19, 10]. Thus, the reduction in chlorophyll content of polluted site roadside plants attributes to high levels of vehicular air pollution [1].

It is well evident that chlorophyll content of plants varies from species to species; age of leaf and also with the pollution level [7]. The higher levels of total chlorophyll content of plants species may be due to its tolerance nature [6]. Therefore, plants maintaining their chlorophyll contents even under polluted environment are said to be tolerant ones [17].

\subsection{Ascorbic Acid AA}

The ascorbic acid content was found to be maximum in both Tabernaemontana and Sesbania in October 2019 (2.0 and 1.66) and minimum values were observed in August 2019 (0.4487 and 0.2692) in both plants. Figure $1 \&$ Figure 2.

Ascorbic acid is known to play an important role in cell wall synthesis, photosynthetic carbon fixation and cell division [9]. It is also a natural antioxidant known to be able to prevent the damaging effect of air pollutant in plant tissue [13]. Its 
reducing power is directly proportional to its concentration [14, 2]. The high amount of ascorbic acid helps in increasing pollution tolerance level in plants. It is very important indicator of pollution that is given a top priority and hence used as a multiplication factor in the APTI formula [2].

\subsection{Relative Water Content}

The relative water content was found to be maximum in month of March 2020 (85.16) and January 2020 (70.85) in Tabernaemontana and Sesbania respectively, whereas minimum values were observed in November 2019 (41.79 and 36.81 ) in both the plants. Figure $1 \&$ Figure 2.

Relative water content of a leaf is the water which is present in it relative to its full turgidity. High water content within plant body helps to maintain its physiological balance under stress conditions such as exposure to air pollution when the transpiration rates are usually high [8]. Due to the air pollution, there is reduction in transpiration rate and damage to the leaf engine that pulls water up from the roots (1-2\% of the total) [8]. Consequently, the plants neither bring minerals nor cool the leaf [8]. Reduction in relative water content in plant species is due to impact of pollutants on transpiration rate in leaves [18].

\subsection{Total Numbers of Vehicles}

Total numbers of vehicles (between 8.00 AM and 4.00 PM) were counted and highest number were recorded in October 2019 (39456) and lowest number was recorded in August 2019 (11987). Figure 1 \& Figure 2.

\subsection{APTI}

Air pollution tolerance index (APTI) of Tabernaemontana was found to be high in March 2020 when it was found to be 9.73 and was lowest in November 2019 when it was 5.08. Air pollution tolerance index (APTI) of Sesbania was found to be high in March 2020 when it was 7.51 and was lowest in November 2019 when it was 4.36. Figure $1 \&$ Figure 2. Average APTI of Tabernaemontana was found to be 7.13 and of Sesbania 5.90 and both the plants fall in the sensitive category [12].

From results obtained from present study, it was observed that Tabernaemontana is more tolerant to air pollution than Sesbania as it has higher APTI value.

\subsection{Correlation Results}

The correlation coefficient values of biochemical parameters viz., total chlorophyll, ascorbic acid, relative water content, and leaf extract $\mathrm{pH}$ and total number of vehicles with air pollution tolerance index (APTI) of selected plant species are presented in tables 1 and 2 .

APTI showed a positive correlation with $\mathrm{pH}, \mathrm{RWC}$, and ascorbic acid but negative correlation with total chlorophyll and total number of vehicles in case of Tabernaemontana. Total number of vehicles passing by was found to be positively correlated with ascorbic acid and total chlorophyll. Similarly in Sesbania APTI showed a positive correlation with, relative water content, and total chlorophyll and negative correlation with ascorbic acid, $\mathrm{pH}$ and total number of vehicles.

The results indicate that when the number of vehicles were more (more pollution), less $\mathrm{pH}$ and high total chlorophyll values were observed in Tabernaemontana, while in Sesbania leaves $\mathrm{pH}$ increased and total chlorophyll value decreased. Ascorbic acid increased in leaves of both the plants with increase in number of vehicles while relative water content decreased in both the plant species with increase in number of vehicles.

Table 1. Correlation between different biochemical parameters, number of vehicles and APTI values of Tabernaemontana at study area.

\begin{tabular}{lllllll}
\hline Parameters & Ascorbic acid & Total Chlorophyll & $\mathbf{p H}$ & Relative water content & APTI & Total number of vehicles \\
\hline Ascorbic acid & 1 & & & & & \\
Total Chlorophyll & -0.32 & 1 & & & & \\
pH & -0.42 & -0.08 & 1 & 1 & 1 & \\
Relative water content & 0.27 & -0.43 & 0.14 & 1 & -0.20 & 1 \\
APTI & 0.43 & -0.49 & 0.18 & 0.97 & -0.28 & \\
Total number of vehicles & 0.31 & 0.21 & -0.63 & -28 & \\
\hline
\end{tabular}

Table 2. Correlation between different biochemical parameters, number of vehicles and APTI values of Sesbania (Vegetable humming bird tree) at study area.

\begin{tabular}{lllllll}
\hline Parameters & Ascorbic acid & Total Chlorophyll & $\mathbf{p H}$ & Relative water content & APTI & Total number of vehicles \\
\hline Ascorbic acid & 1 & & & & & \\
Total Chlorophyll & -0.33 & 1 & & & & \\
pH & 0.45 & 0.01 & 1 & & & \\
Relative water content & -0.60 & 0.36 & -0.42 & 1 & 1 & \\
APTI & -0.43 & 0.35 & -0.30 & 0.98 & -0.23 & 1 \\
Total number of vehicles & 0.47 & -0.41 & 0.20 & -0.20 & \\
\hline
\end{tabular}

\section{Conclusion}

Based on the result obtained after calculating APTI of two different plants from heavy industrial area (HI) Phase II site it can be concluded that different plants respond differently to air pollution. Plants growing in apparently polluted environment have higher APTI from less polluted environment. From results obtained from present study, it was observed that Tabernaemontana is more tolerant to air pollution since it have more APTI value than Sesbania, although both fall in sensitive category. The results indicate that plants in industrial area are continuously exposed to the air pollutants and plants like Tabernaemontana with higher 
APTI values can be used as a sink to control air pollution in these polluted areas.

Thus, this study provides useful information for selecting tolerant plant species for future development and abatement of air pollution because today reducing air pollution is not only a necessity but a compulsion, as we have only one planet to live.

\section{References}

[1] Aasawari A. Tak, and Umesh B. Kakde., (2017), Assessment of air pollution tolerance index of plants: a comparative study, International Journal of Pharmacy and Pharmaceutical Sciences 9, (7), ISSN- 0975-1491.

[2] Agbaire, P. O., and Esiefarienrhe, E., (2009). Air pollution tolerance indices (APTI) of some plants around Otorogun gas plant in Delta state, Nigeria. J. Applied Sci. Environ. Manage., 13: 11-14.

[3] Anthony P. (2001). Dust from walking tracks, impact on rainforest leaves on epiphylls. Co-operative Res Center for Tropical Rainforest Eco and Management, Australia.

[4] Arnon, D. I. (1949). Copper Enzymes in isolated Chloroplasts polyphenol oxidase in Beta vulgaris. Plant Physiol. 24 (1), 115.

[5] Escobedo, F. J., Wagner, J. E. and Nowak, D. J. (2008) Analyzing the cost effectiveness of Santiago, Chile's policy of using urban forests to improve air quality, Journal of Environmental Management. 86, 148-157.

[6] Jyoti J. S., and Jaya, D. S. (2010). Evaluation of air pollution tolerance index of selected plant species along road sides in Thiravananthapuram, Kerala. J. Environ Bio 31: 379-386.

[7] Katiyar V, and Dubey P. S. (2001) Sulphur dioxide sensitivity on two stage of leaf development in few tropical tree species. Indian J Environ Toxicol; 11, 78-81.

[8] Lohe, R. N., B. Tyagi., V. Singh., P. Kumar Tyagi., D. R. Khanna., and R. Bhutiani (2015) A comparative study for air pollution tolerance index of some terrestrial plant species, Global J. Environ. Sci. Manage, 1 (4): 315-324, DOI: 10.7508/gjesm.2015.04.006.

[9] Madan, Sangeeta., and Verma, Pooja., (2015) Assessment of air pollution tolerance of some trees in Haridwar City, Uttarakhand, Journal of Environmental Biology, 36, 645-648.
[10] Mir Q. A, Yazdani T, Kumar A, Narain K, and Yunus M. (2008) Vehicular population and pigment content of certain avenue trees, Pollut Res, 27 (1), 59-63.

[11] Nadgórska-Socha, Aleksandra., Barczyk, Gabriela., Kandziora-Ciupa, Marta., Trzęsicki, Michał., (2017), Air pollution tolerance index and heavy metal bioaccumulation in selected plant species from urban biotopes, Chemosphere 183, 471-482, DOI: 10.1016/j.chemosphere.2017.05.128.

[12] Namrata, D. and Sandeep, P. (2006). Evaluation of local plants for bio-monitoring of air pollution by Air Pollution Tolerance Index (APTI) in Satna city (MP). Nat. J. Life Sci. 525-527.

[13] Nayak, Anjali., Madan, Sangeeta and Matta, Gagan., (2018). Evaluation of Air Pollution Tolerance Index (APTI) and Anticipated Performance Index (API) of Some Plants Species in Haridwar City, International Journal for Environmental Rehabilitation and Conservation, IX (1), ISSN: 0975-6272 $1-7$.

[14] Raza, S. H. and Murthy, M. S. R. (1988). Air pollution tolerance index of certain plants of Naacharam industrial area, Hyderabed. Indian J. Bot., 11 (1), 91-95.

[15] Rupa, P., and Venkatachalam T, (2017), Evaluation of air pollution tolerance index of the floras in the manufacturing zone near Coimbatore in India and certification of forbearing types, Int. Res. J. Pharm., 8 (8), ISSN 2230-8407.

[16] Singh, S. K. and Rao, D. N., (1983) Evaluation of the plants for their tolerance to air pollution, Proc Symp Air Pollutio Control held at IIT, 218-224.

[17] Singh, S. N. and Verma, A. (2007). Phytoremediation of Air pollution: A review in book Environmental Bioremediation Technology, (Singh S. N and Tripathy, R. D (eds), Publisher Springer, Berlin Heidelberg, 293-314.

[18] Swami, A., Bhatt, D. and Joshi, P. C., (2004). Effects of automobile pollution on Sal (Shorea robusta) and Rohini (Mallotus phillipinensis) at Asarori, Dehradun. Himalayan J. Environ. Zool, 18 (1), 57-61.

[19] Tripathi A. K, and Gautam M.. (2007) Biochemical parameters of plants as indicators of air pollution, $\mathrm{J}$ Environ Biol, 28, 127-32.

[20] Zouari, M., Elloumi, N., Mezghani, I., Labrousse, P., Ben Rouina, B., Ben Abdallah, F. and Ben Ahmed, C., (2018) A Comparative Study of Air Pollution Tolerance Index (APTI) of Some Fruit Plant Species Growing in the Industrial Area of Sfax, Tunisia, Pollution, 4 (3): 439-446. 